\title{
Title: Understanding the role of vayu and akash mahabhuta in the mutations in tyrosine kinase portion of insulin receptor gene found in niddm patients.
}

\section{Authors: Kulkarni D. V. ${ }^{1}$, Shinde Sneha $\operatorname{Pramod}^{2}$, Kharosekar Purwa ${ }^{3}$}

1. Professor and HOD, (Dravyaguna),

2. PG Scholar (Dravyaguna)

3. PG Scholar (Dravyaguna)

Government Ayurveda College, Osmanabad, Maharashtra. 413501.

*Corresponding Author: Email: snehashinde872@gmail.com; Mob.No.: 9405766106

\section{Abstract:}

Normally, when insulin binds to the extracellular alpha chain of the insulinthat the replacement of Vayu mahabhuta and Akash mahabhuta by Prithvi mahabhuta and Jala mahabhuta, is the backbone of the pathology in NIDDM. receptor, it originates a change within receptor's structure, resulting autophosphorylation of particular tyrosin in the cytoplasmic part of the beta chains. This change causes an initiation of a multifaceted cascade, which lastly results in secretion of the insulin.

It is a well-known fact that the determination of any function of a protein is dependent on the sequence of the amino acids. Obviously any changes in the sequence result in differed function. This change is called as mutation. It is an established fact that missense mutations in the tyrosine kinase portion of the insulin receptor gene are present in patients with NIDDM. This mutation in the insulinreceptor prevents the relay of the stimuli, resulting in inhibition of insulin secretion finally.

Here, we have demonstrated that the mutations in tyrosine kinase portion of insulin receptor gene found in the patients of NIDDM, are actually the derangement in the ruksa, laghu attributes, which are due to the combination of Vayu mahabhuta and Akash mahabhuta. We have also concluded

\section{Introduction:}

Diabetes Mellitus is well-known for its mortality and morbidity since centuries. Since thousands of years, Indians are well aware of the Prameha, especially vataj prameha or Madhumeha. There are hundreds of medicinal herbs known for their antidiabetic activity. Caraka has described 20 types of Prameha. He has also emphasized on the fact that all the prameha are converted in to Madhumeha, if untreated. As India is becoming a hometown for the diabetes mellitus, it is a big challenge for the medical fraternity to cope with the disease. In this review, we have considered the famous ayurvedic herb 
Momordica charantia for the interpretation of the insulin function and it co-relation with activity of vata dosha.

\section{Understanding the herbal drug Momordica charantia: -}

Karvellaka is the Sanskrit name of the Momordica charantia, which is in possession of tikta rasa and laghu, ruksa attributes. Bhavprakash has described it as "mehahara"[26]. It is cultivated all over India for its fruits. The claim of its hypoglycaemic activities is found in fruits and seeds mainly. Lolitkar, M.M.et.al,(1966) demonstrated that "charantin" isolated from Momordica charantia bears a similarity to insulin activity for lowering the blood glucose level in rabbits. ${ }^{[1]}$ Khanna P. and others (1981) also established the fact that compounds isolated from the fruit and seeds of Momordica charantia contribute to its hypoglycaemic activity. They also proved that "charantin" and "polypeptide p" have a resemblance with insulin. Ojewole and others established that the mechanisms of action of hypoglycaemic effect of Momordica charantia are due to insulin like peptide (polypeptide p-insulin). They also claimed that aqueous extract of Momordica charantia mimics insulin action not only at cellular level but at extrapancreatic level also ${ }^{[3]}$. Tayyab F. and others (2012) isolated insulin like hypoglycaemic protein ( $\mathrm{p}$-insulin) from fruit, seeds, and leaves of Momordica charantia. This polypeptide was found to lower blood glucose levels in humans when injected subcutaneously. ${ }^{[4]}$ Paul A. and Raychaudhari SS (2010) also demonstrated that p-insulin derived from Momordica charantia works by imitating the action of human insulin and can be used as plant based insulin replacement in patients with type 1 diabetes mellitus. ${ }^{[5]}$ Baldwa V. S.et.al. (1997) also isolated an insulin-like compound from fruit and tissue culture of Momordica charantia. They demonstrated that, this plant insulin has 17 amino acids in two chains bound together with sulphide bond. They also established the fact that the infrared spectrum of this plant insulin super imposes on standard zinc crystalline bovine insulin. ${ }^{[6]}$ Zhang Q $\mathrm{C}$ also established the $\mathrm{p}$ insulin structurally and pharmacologically comparable to bovine insulin and its subcutaneous and intramuscular administration produces hypoglycaemic effect in diabetic patients for more than 6 hrs., as compare to $2 \mathrm{hrs}$., for bovine insulin. ${ }^{[7]}$ Yibchok-Anun S. and others (2006) isolated a slow acting protein extract from fruit pulp of Momordica charantia and it showed insulin secreting and insulinlike activities. ${ }^{[8]}$ Pitipanapong J.et.al.,(2007) also demonstrated that sitosteryl-glucoside and stigma steryl glucoside from "charantin" can be used as a replacement therapy for insulin. ${ }^{\left[{ }^{9]}\right.}$ Paul A, Raychaudhari SS.(2010) established that plant insulin found in seeds and fruits of Momordica charantia is in possession of similarity to the composition of insulin. They demonstrated the use of this plant-insulin in e therapy of type 1 diabetes mellitus. ${ }^{[10]}$ updating the anti-diabetic plants, and heir active constituents Marles, R. and Farnsworth, N. (1997) established that Momordica charantia is one of the most popular anti-diabetic plant worldwide and it is referred as "vegetable-insulin" in Asia. ${ }^{[11]}$ Parkash A et.al.,(2002) showed that "charantin", a peptide isolated from Momordica charantia resembles with insulin but it decreases blood sugar level on temporary basis. ${ }^{[12]}$ Many research workers search that the effect of the powder and chloroform extract of Momordica charantia in comparison with insulin in both age match control and STZ induced diabetic rats. Cummings E and others, have clearly demonstrated that Momordica charantia contains insulin similar property similar to 1 phyto chemical component of Momordica charantia called "v-insulin" ${ }^{\text {[13] }}$ Hanhineva $\mathrm{K}$ and others (2010), demonstrated that extract of Momordica charantia can stimulate glucose uptake into skeletal muscle cell just like insulin and this effect is exerted via the same intracellular 
signalling pathways as insulin in regulating glucose metabolism in body. ${ }^{[14]}$

Figure No.1 illustrates the 80 out of total 172 hydrophobic amino acids which are found in the hypoglycaemic peptide from Momordica charantia.

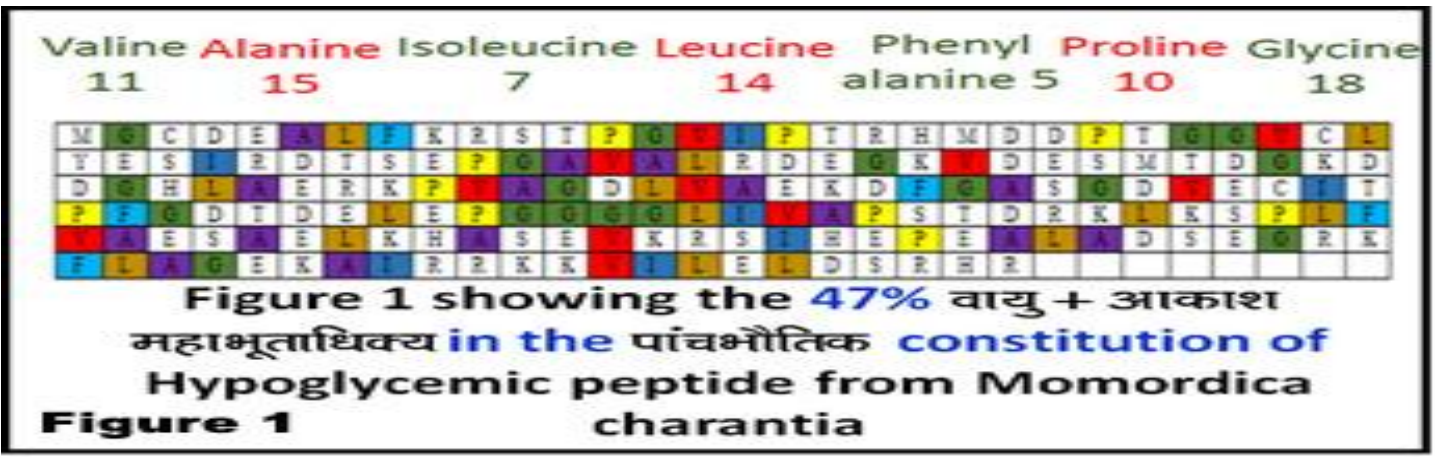

\section{Understanding the Insulin-}

To understand the working of insulin properly, we must have to look a structure of insulin which is shown in fig.2. Insulin

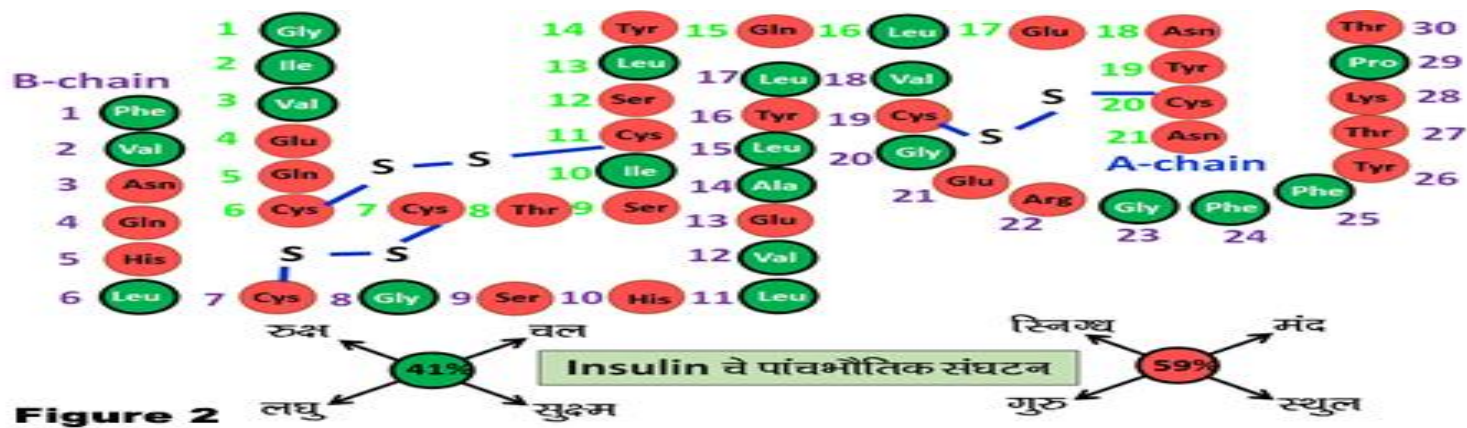

consists of two polypeptide chains, namely chain A and chain B. Both A and B chains are attached together by disulphide bonds. Actually insulin is synthesized in beta cells of islets of Langerhans as a single polypeptide called 'pre-proinsulin'. This proinsulin is converted into mature insulin, which is wrapped inside mature granules and is made available to be exocytose from cell into the circulation on metabolic signals.

Structure-function studies have indicated that amino acids essential for binding to the insulin receptor, include A1Gly, A2Ile, A3Val, A19Tyr, B6Leu, B12Val, B23Gly, $\mathrm{B} 24 \mathrm{Phe}$ and B25Phe ${ }^{[15,16,17]}$. Out of these 9 amino acids essential for the binding, except Tyrosine remaining all 8 amino acids, being hydrophobic, are in possession of ruksa, laghu, khara, suksma, cala qualities of vatadosa.

Considering the fig. 2 we can observe that, in the A chain there are 6 out of $21(29 \%)$ such amino acids and in the chain B there are 15 out of $30(50 \%)$ such amino acids, which are hydrophobic in nature. We know that those entities, which are hydrophobic in nature, are in possession of vayumahabhuta and Akasamahabhuta in their paamcabhautika constitution. So in the long run, they are in possession of ruksa, laghu, khara, suksma, cala qualities of 


\begin{tabular}{|c|c|c|c|c|c|c|c|}
\hline Approximately 100 Gm serving & Ruksha & laghu & Sheeta & $\begin{array}{l}\text { Vata } \\
\text { kara }\end{array}$ & $\begin{array}{l}\text { Alanine } \\
\text { (in mg) }\end{array}$ & $\begin{array}{l}\text { Glycine } \\
\text { (in } \mathrm{mg} \text { ) }\end{array}$ & $\begin{array}{l}\text { Proline } \\
\text { (in mg) }\end{array}$ \\
\hline Peanut $^{[19]}$ & Yes & Yes & Yes & Yes & 1.04 & 0.94 & 1.14 \\
\hline Lentil pink $^{[20]}$ & Yes & Yes & Yes & Yes & 1.05 & 1.01 & 1.05 \\
\hline Flat beans ${ }^{\lfloor 21]}$ & Yes & No & No & Yes & 0.98 & 1.01 & 0.88 \\
\hline Bengalgram $^{[22]}$ & Yes & Yes & Yes & Yes & 0.83 & 1.55 & 0.80 \\
\hline Red Gram ${ }^{[23]}$ & Yes & Yes & Yes & Yes & 1.08 & 0.82 & 0.95 \\
\hline Red kidney beans ${ }^{[20]}$ & Yes & Yes & Yes & Yes & 0.99 & 0.92 & 0.95 \\
\hline Kidney bean aconite leaved $^{[24]}$ & Yes & Yes & No & Yes & 0.98 & 1.02 & 0.97 \\
\hline Mung beans ${ }^{[25]}$ & Yes & Yes & Yes & Yes & 1.04 & 0.95 & 1.09 \\
\hline French beans ${ }^{\lfloor 21]}$ & Yes & Yes & Yes & Yes & 0.79 & 0.73 & 0.79 \\
\hline
\end{tabular}

Table No.1

If we try to understand the meaning from hendrolysed, most food proteins set table no.1, which shows some of the free bitter tasting peptides. Hydrolysates of regular protein rich food particles of an Nustios trophilic proteins such as gelatine, are Indian diet, we can make two observations from this diet. First we can see that the average $\%$ of the hydrophobic amino acids is nearly $38 \%$ of the total proteins in the food particles, second thing is that all this food items, which are having $38 \%$ average hydrophobic amino acids are actually in possession of ruksa and laghu attributes and are recognise as "vatakara". So one can conclude that the diet containing excess amount of food particles showed in above table, results in the increase in the percentage of hydrophobic amino acids in body, causing enhancement in the ruksa and laghu attributes throughout the body. As increase in the ruksa and laghu attributes represents the increase in the activities of vatadosa. So these food particles are labelled as "vatakara".

\section{Hydrophobic amino acids come under the umbrella of vata dosa} less bitter that the hydrolysates of hydrophobic protein such as caseins and soya proteins. The bitterness is mentioned in Ayurveda as tikta rasa, which is the result of the combination of Vayu mahabhutaand Akasa mahabhuta in their paamcabhautika constitution. So basically, the entities having Vayu mahabhuta and Akasa mahabhuta as main components can labelled as coming under the classification of hydrophobic entities. On the other hand, the entities having Prithvi mahabhuta and Jala mahabhuta as the main component in their paamcabhautika constitution, can be recognised as coming under the classification of hydrophillic substances.

Now we have a clear understanding that the hydrophobic amino acids come under the umbrella of vatadosa. So when in a constitution of an entity, amino acids belonging to the hydrophobic class are in excess percentage, then we can have 
labelled the entity belonging to vatakara class.

This discussion leads us to the conclusion that insulin can be classified as an instrument for the functionality of vatadosa. As we are aware of the fact that in the glucose metabolism, insulin only have an act of stimulation to facilitate the entry of glucose into the cell. Once insulin has facilitated the entry of glucose into the cell, then after, insulin has no role into the production of ATP from glucose.

So fundamentally, insulin only is a stimulator for specific activity. This stimulation can be labelled as an activity of cala quality of vatadosa. Then the question arises, how we can compare the stimulation activity of insulin with the work done by cala qualities of vatadosa. For this, we should again have a look at the structure of insulin. In the constitution of insulin, we can see that 21 out of $51(41 \%)$ amino acids belong to the hydrophobic class and ultimately are in possession of the combination of Vayu mahabhutaand Akas mahabhuta definitely resulting in the possession of vatakara property with itself. This is the cause we say that insulin is in possession of cala quality of vatadosa and works as a stimulator. Hemadri has also said that "prerane cala". This prerana means stimulation by vatadosa.

\section{Understanding the Insulin-receptor}

We know that many enzymes are synthesized as inactive precursors. Afterwards they are triggered by cleavage of one or a few specific peptide bonds. Cleavage means the act of splitting or dividing. In the creation of an insulinreceptor, a proteolytic cleavage of polypeptide-chain precursor takes place. In this process alpha and beta chains, which are linked by two disulphide bonds, are produced. As shown in figure 3, the alpha chain, responsible for the insulin binding is completely extracellular, on the other hand, the beta chain is divided in three parts. First one is a small extra-cellular region, in continuation the second one is in the membrane region and the third one is intracellular tyrosine kinase. One of the most outstanding features of the insulin receptor is the existence of an autophosphorylation site at the Tyr 1162 position. Steven R Hubbard and others (1994) have shown that the position of the main chain, at the position Tyr 1162 is resolute or determined by the loop of residues positioned at Leucine 1171 to Alanine $1177^{[18]}$. As Leucine, Alanine, and Valine are hydrophobic amino acids, they are in possession of the attributes belonging to Vayu mahabhuta and Akasa mahabhuta . In this loop, Leu1171, and Val 1173, together with Leu 1181 and Leu 1219, form a cluster of ruksa, laghu, khara, suksma, cala qualities of vatadosa.

* nother important thing is that, the side hain of Tyr 1163 also resides in Vayaviya and Akashiya environment, which is formed by Valine 1173 and Leucine 1219.

\section{Discussions:}

\section{Mutation in the Ruksha, Laghu attributes of tyrosine kinase}

It is a well-known fact that the determination of any function of a protein is dependent on the sequence of the amino acids. Obviously any changes in the sequence result in differed function. This change is called as mutation. If the substitution is of one amino acid for another amino acid in the protein, then it is called as missense mutation. 


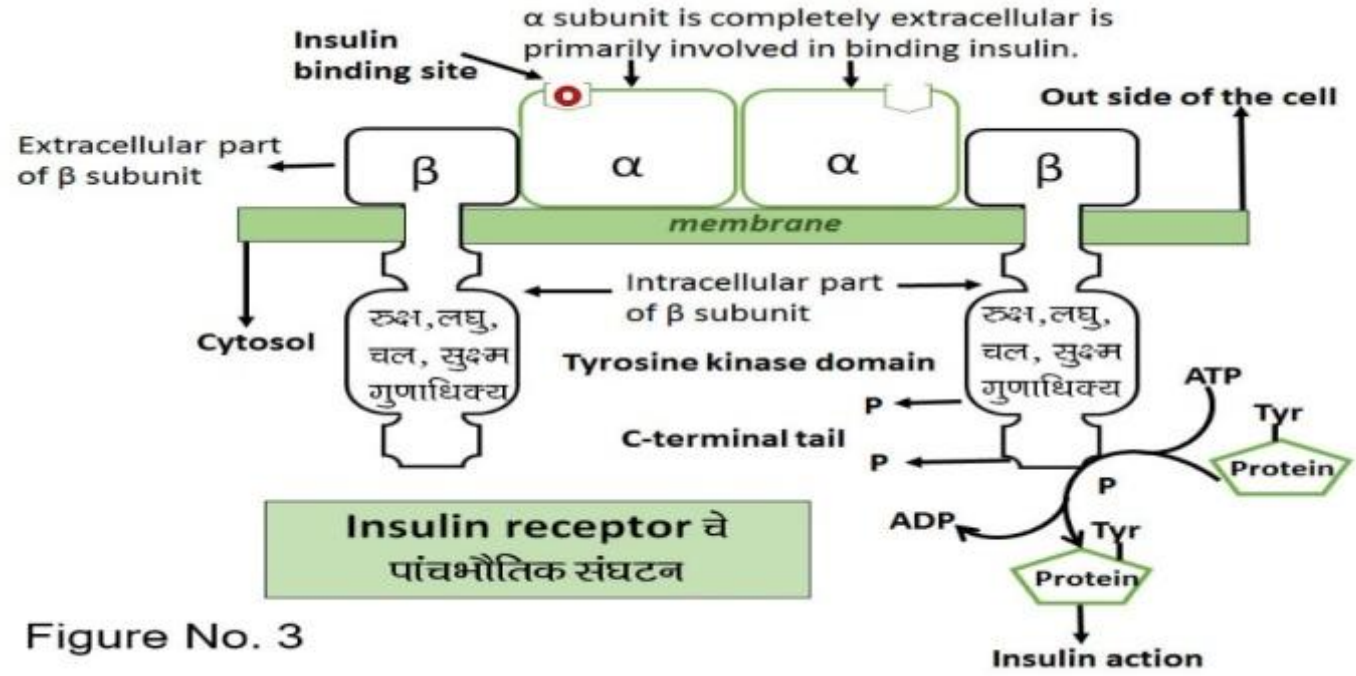

The missense mutations in the tyrosine kinase portion of the insulin receptor gene that have been found in patients with NIDDM are mapped onto the insulin structure in this figure. Many of these mutations include replacement of hydrophobic residues with other of different size or with charged residues. Steven R Hubbard and others (1994) demonstrated how the mutation destabiliz the hydrophobic packing in the C-termin lobe ${ }^{[4]}$.

1. Glycine at the 1008 position, in the tyrosine kinase portion of the insulin receptor, is in possession of ruksa and laghu qualities. On the other hand, threonine 1031 and Asparagine 1033, two residues of the main chain, which remain nearest to the Glycine 1008 position, are actually in possession of attributes belonging to Prithvi mahabhuta and Jala mahabhuta. So when due to the mutation, Glycine 1008 is replaced by Valine, there is no room available for the side chain of Valine residue, due to the neighboring presence of Parthiva and Jaliya threonine and asparagine.

2. As we know Aspartate, being a negatively charged and polar amino acid, is in possession of these qualities, which are due to the combination of to pruthvimahabhuta and Jalamahabhuta in its paamcabhautika constitution.
Normally, Alanine 1048C $\beta$, an amino acid belonging to Vayu mahabhuta and Akasa mahabhuta, are in possession of ruksa and laghu qualities and is seated in the hydrophobic pocket. So when in the missense mutation, Asparatate takes place of Alanine $1048 \mathrm{C} \beta$, it is not accomodated in that pocket due to its larger size.

Threonine and Glutamic acid, both amino acids are also in possession of attributes belonging to Prithvi mahabhuta and Jala mahabhuta. So in the mutation when theses two amino acids take place of Alanine 1134 and Alanine 1135 respectively in the catalytic loop, which belong to Vayu mahabhuta and Akasa mahabhuta, there is a steric clash in between them, causing destabilisation of the hydrophobic packing in the $\mathrm{C}$-terminal lobe.

When the insulin binds to the extracellular alpha chain, it originates a change within the insulin-receptor structure, resulting in autophosphorylation of particular tyrosines in the cytoplasmic part of the beta chains. This change causes the recruitment of intracellular signalling molecules, which then initiate a multifaceted cascade of phosphorylation and de-phosphorylation reactions. This results in the spread of metabolic effects of insulin. One of the 
important result is the activation of the phosphatidylinositol-3'-kinase (PI-3kinase) pathway. After activation this pathway motivates translocation of glucose transporters (GLUT4) to cell surface. This translocation is very important for glucose uptake by the cell.

\section{Conclusion:}

The most amazing thing about Momordica charantia is that it is in possession of $\mathrm{p}$ insulin, which is structurally and pharmacologically analogous to bovine insulin. We have established in this work that the ayurvedic description of Momordica charantia and its paamcabhautika attributes are equivalent to the paamcabhautika structure of insulin.

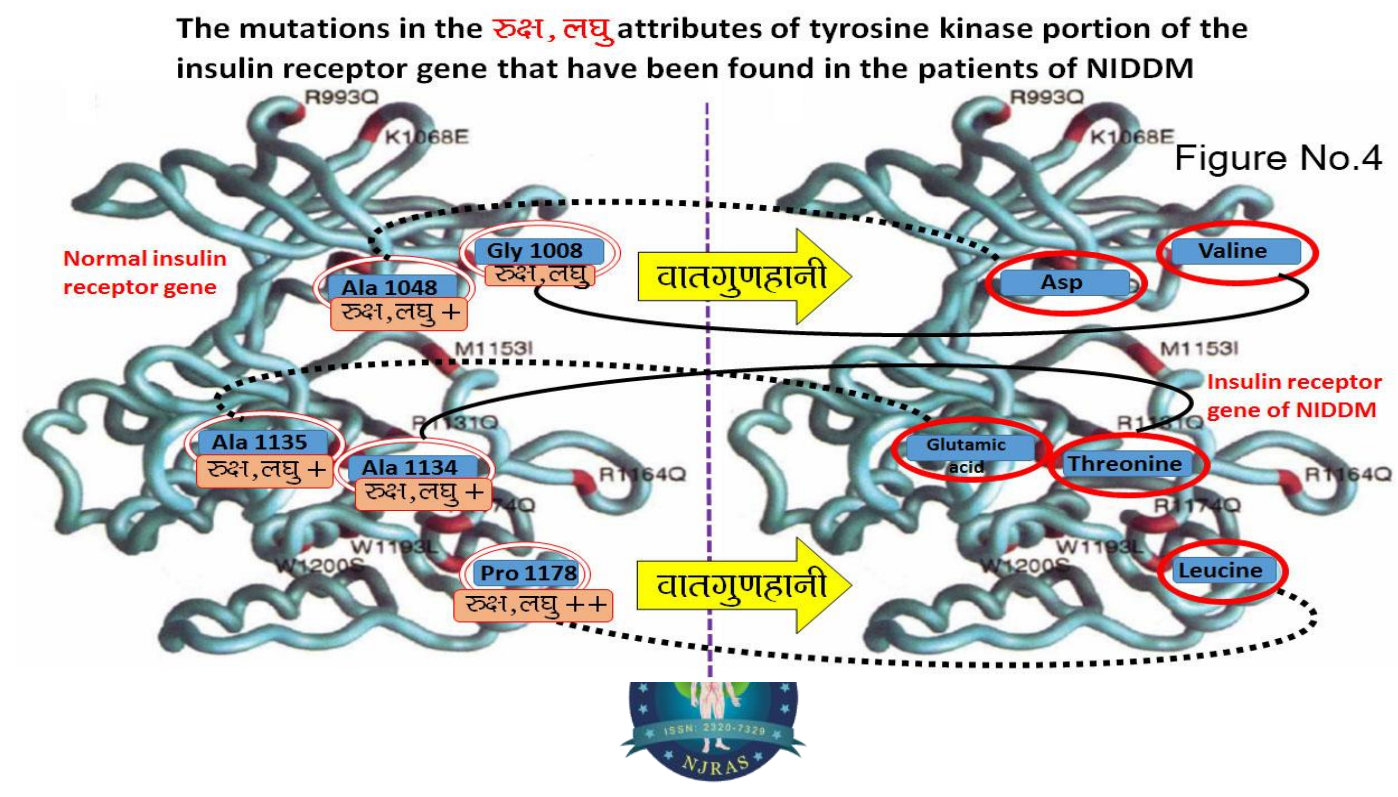

Here, we have recognized that the mutations in tyrosine kinase portion of insulin receptor gene, found in the patients of NIDDM, are actually the derangement in the ruksa, laghu attributes, which are due to the combination of Vayu mahabhuta and Akash mahabhuta. We have concluded that the replacement of Vayu mahabhuta and Akash mahabhuta by Prithvi mahabhuta and Jala mahabhuta is the backbone of the pathology in the patients of NIDDM. Momordica charantia is mainly in possession of tikta rasa, which is formed by the combination of Vayu mahabhuta and Akash mahabhuta. Administration of Momordica charantia has a definite impact on the activity of vatadosa. So we have confirmed that Momordica charantia shows anti-diabetic activity by increasing the Ruksha and Laghu attributes of vata dosa.
References:

1. Lolitkar, M.M., Rao, M.R.R. (1966). Pharmacology of a hypoglycemic principle isolate from fruit of Momordica charantia Linn. Ind. J. Pharmacy, 28:129-133.

2. Khanna P., Jain, S.C., Panagariya, A. And Dixit, V.P. (1981).Hypoglycemic activity of polypeptide-p from a plant source. J. Nat. Prod., 44: 648-655.

3. Ojewole, John AO. Adewole, Stephen O. Olayiwola, Gbola. Hypoglycemic and hypotensive effects of Momordica charantia aqueous extract in rats. Cardiovasc J. South Afr 2006; 17: 227 -232 .

4. Tayyab F., Lal SS, Mishra K, Kumar U. A review: Medicinal plants and its impact on diabetes. World J Pharm Res 2012; 1(4):1019-1046. 
5. Paul A, Raychaudhari SS, Medicinal uses and molecular identification of two Momordica charantia varieties- a review. E J Bio 2010; 6(2): 43-51

6. Baldwa V S, Bhandari C M, Pangria A, Goyal R K. Clinical trial in patients with Diabetes Mellitus of an insulinlike compound obtained from plant source. Ups J Med Sci 1997,82: 39-41.

7. Zhang Q C. Preliminary report on the use of Momordica charantia extract by HIV patients. JNaturopathic Med 1992, 3: 659

8. Yibchok-Anun S, Adisakwattana S, Yao CY, et al. (2006) Slow acting protein extract from fruit pulp of Momordica charantia with insulin secretagogue and insulinomimetic activities. Biol Pharm Bull 29: 11261131.

9. Pitipanapong J, Chitprasert S. Goto M, Jiratchariyakul W, Sasaki M, Shotipruk A. New approach for extraction of charantin from Momordica charantia with pressurized liquid extraction. Separat Purification Technol. 2007; 416-22.

10. Paul A, Raychaudhuri SS, Medicinal uses and molecular identification of two Momordica charantia varieties - a review. E J Biol. 2010; 6(2): 43-51.

11. Marles, R. and Farnsworth, N. (1997). Antidiabetic plants and their active constituents: An update. Phytomedicine, 2, 137-189. doi:10.1016/S0944-7113(11)80059-0

12. Parkash A, Ng TB, Tso WW. Purification and characterization of charantin, a napin-like ribosomeinactivating peptide from bitter gourd (Momordica charantia) seeds. J Pept Res 2002; 59:197-202.

13. Cummings E, Hundal HS, Wackerhage $H$, Hope $M$, Belle $M$, Adeghate $E$, Singh. "Momordica charantia fruit juice stimulates glucose and amino acid uptakes in L6 myotubes."JourMol Cell Biochem. 2004 Jun; 261(1-2):99-104.

14. Hanhineva K, Törrönen R, BondiaPons I, Pekkinen J, Kolehmainen M,
Mykkänen H, Poutanen K. "Impact of dietary polyphenols on carbohydrate metabolism".Int J Mol Sci. 2010 Mar 31; 11(4):1365-402.

15. Kristensen C, Kjeldsen T, Wiberg FC, Schäffer L, Hach M, Havelund S, Bass J, Steiner DF, Andersen AS: Alanine scanning mutagenesis of insulin. $J$ Biol Chem 272:12978-12983, 1997.

16. Gammeltoft $\mathrm{S}$ : Insulin receptors: binding kinetics and structure-function relationship of insulin. Physiol Rev.1984 ; 64: 1321-1378

17. Kaarsholm NC, Ludvigsen S: The high resolution solution structure of the insulin monomer determined by NMR. Receptor.1995; 5: 1-8

18. Steven R Hubbard, Lei Wei, Leland Ellis and Wayne A. "Crystal structure of the tyrosine kinase domain of the human insulin receptor." Hendrickson; Nature. December 1994; 372: 22-29

19. Dr. Indradeo Tripathi. Raj Nighantu (Hindi translation). $3^{\text {rd }}$ ed. Varanasi; Chaukhamba Bharati Academy. 2003. Shalyadi varga, verse no.97, pg 547

. Vaidya Laxmipati sastri. Edited by Bhisagratna Brahmasankar Sastri. Yogratnakar with 'vidyotini'Hindi commentary. Varanasi; Chaukhamba Prakashan. Reprinted 2015. Dhanyadi phalashakaguna, verse no.04, pg 25

21. Dr. Gangasahay Pandey \& Prof. Krushnachandra Chunekar. Bhavprakash Nighantu (Hindi translation). $\quad 7^{\text {th }}$ ed. Varanasi; Chaukhamba Bharati Academy. 1986. Reprinted 2015. Dhanyavarga, verse no.46, pg 633

22. Dr. Indradeo Tripathi. Raj Nighantu (Hindi translation). $3^{\text {rd }}$ ed. Varanasi; Chaukhamba Bharati Academy. 2003. Shalyadi varga, verse no.85, pg 545

23. Dr. Gangasahay Pandey \& Prof. Krushnachandra Chunekar. Bhavprakash Nighantu (Hindi translation). $\quad 7^{\text {th }}$ ed. Varanasi; Chaukhamba Bharati Academy. 1986. Reprinted 2015. Dhanyavarga, verse no.51-52, pg 635 
24. Dr. Indradeo Tripathi. Raj Nighantu (Hindi translation). $3^{\text {rd }}$ ed. Varanasi; Chaukhamba Bharati Academy. 2003. Shalyadi varga, verse no.93, pg 547

25. Dr. Indradeo Tripathi. Raj Nighantu (Hindi translation). $3^{\text {rd }}$ ed. Varanasi; Chaukhamba Bharati Academy. 2003. Shalyadi varga, verse no.77-78, pg 543
26. Dr. Gangasahay Pandey \& Prof. Krushnachandra Bhavprakash ed. Varanasi; Chaukhamba Bharati Academy. 1986. Reprinted 2015. Shaka varga, verse no.64,pg 671

\section{Ethical committee permissions details: None}

\section{Conflict of Interest: Non}

\section{Cite article:}

Understanding the role of vayu and akash mahabhuta in the mutations in tyrosine kinase portion of insulin receptor gene found in niddm patients. 